\title{
QUALITY CHARACTERISTICS OF SURFACE WATERS AT ASPROLAKKAS RIVER BASIN, N.E. CHALKIDIKI, GREECE
}

\author{
Kelepertzis E. ${ }^{1}$, Argyraki A. ${ }^{1}$, Daftsis E. ${ }^{2}$ and Ballas D. ${ }^{2}$ \\ ${ }^{1}$ Department of Economic Geology and Geochemistry, University of Athens, 15784 Athens - Greece, \\ kelepert@geol.uoa.gr,argyraki@geol.uoa.gr \\ ${ }^{2}$ Hellas GoldS.A.,edaftsis@hellas-gold.com,dballas@hellas-gold.com
}

\begin{abstract}
The present study reports on a four sampling period (April 2008-July 2008-November 2008-February 2009) study of water quality in streams of NE Chalkidiki. A total of 80 surface water samples were collected and analysed for the major ions $\mathrm{Ca}^{2+}, \mathrm{Mg}^{2+}, \mathrm{K}^{+}, \mathrm{Na}^{+}, \mathrm{Cl}^{-}, \mathrm{HCO}_{3}^{-}, \mathrm{SO}_{4}^{2-}, \mathrm{NO}_{3}$ - and the trace elements $\mathrm{Pb}, \mathrm{Fe}, \mathrm{Cd}, \mathrm{Cu}, \mathrm{Cr}, \mathrm{Ni}, \mathrm{Zn}, \mathrm{Mn}$ and As. Also $\mathrm{pH}$, Electrical Conductivity (EC), Total Dissolved Solids (TDS), Temperature, as well as the stream water discharge at each sampling point, were determined in the field. The treatment and the subsequent evaluation of the data showed that the water samples are divided into three separate groups, reflecting the chemistry of water in the three sub-basins of the area i.e., Kokkinolakkas, Kerasia and Piavitsa. The water of the first one is possibly affected by the past mining activities of the area, whereas samples from the other two reflect the influence of sulphide mineralization on the hydrogeochemistry of the corresponding streams. No effect of the seasonal differentiation of stream water discharge was observed.
\end{abstract}

Key words: Asprolakkas Basin, NE Chalkidiki, water quality, mining activities.

\section{Intoduction}

The Asprolakkas stream drains materials from the geological formations of the North East Chalkidiki peninsula, Northern Greece. The deposits of the area have a long exploitation history that started at 600BC and continues today. During the last century, several mining companies exploited the sulphide and the associated manganese oxide ore deposits. In April 2004, the whole Kassandra mines property was transferred by the Greek State to "Hellas Gold S.A.", including the mineral rights in an area of 265 stremmas, the Stratoni Operation $(\mathrm{Pb} / \mathrm{Zn} / \mathrm{Ag})$ and two projects for development, the Olympias carbonate-hosted $(\mathrm{Pb} / \mathrm{Zn} / \mathrm{Au} / \mathrm{Ag})$ and the Skouries porphyry $(\mathrm{Cu} / \mathrm{Au})$. The whole area has already been included in the ProMine Project, financed by the European Union. This project mainly aims at developing the first European GIS-based database containing the known and predicted metalliferous resources and calculating the volumes of potentially strategic metals (e.g. cobalt, niobium, vanadium, antimony, platinum group elements and REE) and minerals that are currently not extracted in Europe. Currently, in the Stratoni Operation, only the Mavres Petres deposit is mined, by overhand drift and fill method using cemented tailings for backfill.

Acid mine water, deriving from both Mavres Petres and Madem Lakkos mines, is directed to the water treatment plant, located next to the Stratoni flotation plant. The treatment is carried out in agitated reactors with hydrated lime $\left(\mathrm{Ca}(\mathrm{OH})_{2}\right)$ for neutralization. Additional measures that have been 
undertaken to prevent and effectively control acid mine drainage even under extreme conditions, include the construction of a new water treatment plant by the entrance of the mine and the closure of the exhausted Madem Lakkos mine by backfilling the old mining voids.

The main objectives of the present study are: a) to determine the physical and chemical characteristics of surface water from the streams running within the Asprolakkas river basin, throughout a hydrologic year, and b) to assess the possible impact of mineralization and mining activity on the hydrogeochemistry of the drainage system.

\section{Site Description}

\subsection{Geology and Mineralization}

Geologically the wider area belongs to the southernmost extension of the Serbo-Macedonian Belt, a series of metamorphic rocks that extends northward into Bulgaria and eastern Yugoslavia (Nebel et al. 1991). The Serbo-Macedonian Massif is divided into two formations: the Vertiskos formation (uppermost member) and the Kerdylia formation (lowermost member) (Kockel et al., 1977). The Kerdylia formation, which is of higher metamorphic grade, mainly consists of migmatitic biotite gneiss interlayered with several marble horizons, amphibolites and hornblende gneiss whereas the Vertiskos sequence, outcropping in the studied area, largely includes biotite-muscovite gneiss and amphibolites with hornblende amphibolite intercalation (Kockel et al., 1977). A fault zone (Stratoni - Varnava fault) separates the two formations, a major structural feature that dominates the area.

The area is also characterised by calc-alkaline postorogenic granitoids of Tertiary age (Nicolaou and Kokonis. 1980, Kalogeropoulos et al., 1989; Kroll et al., 2002): the Stratoni granodiorite (29Ma), the quartz-diorite porphyry of Fisoka and the Skouries shoshonitit porphyry being the host of a porphyry $\mathrm{Cu}$-Au deposit (Figure 1). The intrusion age of Skouries deposit was determined at 19 $\pm 1 \mathrm{Ma}$ (Frei. 1995).

These intrusive bodies are strongly related to various ore deposits in the area. The mineralised zone is often referred to as the Stratoni-Piavitsa belt and the mineralization is classified as $\mathrm{Pb}-\mathrm{Zn}-\mathrm{Ag}$ carbonate replacement type mineralization (Madem Lakkos and Mavres Petres mines), both massive and disseminated in form (Nebel et al., 1991). In addition, the porphyry $\mathrm{Cu}-\mathrm{Au}$ deposits in Skouries and Fisoka, south of Stratoni village, represent another ore type (Kockel et al., 1975) while Mn ores occur along the Stratoni-Varvara fault, especially at the west part of the studied area.

\subsection{Physiography and hydrology}

The area is characterised by mountainous relief with $92 \%$ of the surface covered by mainly deciduous forest. Streams within the Asprolakkas water basin originate from the Stratonikon Mountain and follow a general N-S direction. The three main streams that are studied are flowing through a mountainous landscape within the sub-basins of Piavitsa, Kerasia and Kokkinolakkas. They all discharge their water in Asprolakkas which has an E-W direction flowing towards the Golf of Ierissos. The climate is typical Mediterranean, with rainy winters and dry, warm summers. Flow rates of the streams are rapidly affected by rainfall and present strong variations, according to the pluviometric regime, resulting in the completely dry up of some streams during the summer months.

\section{Methods}

\subsection{Sampling}

Field work was performed in 4 sampling periods: April 2008, July 2008, November 2008 and Feb- 


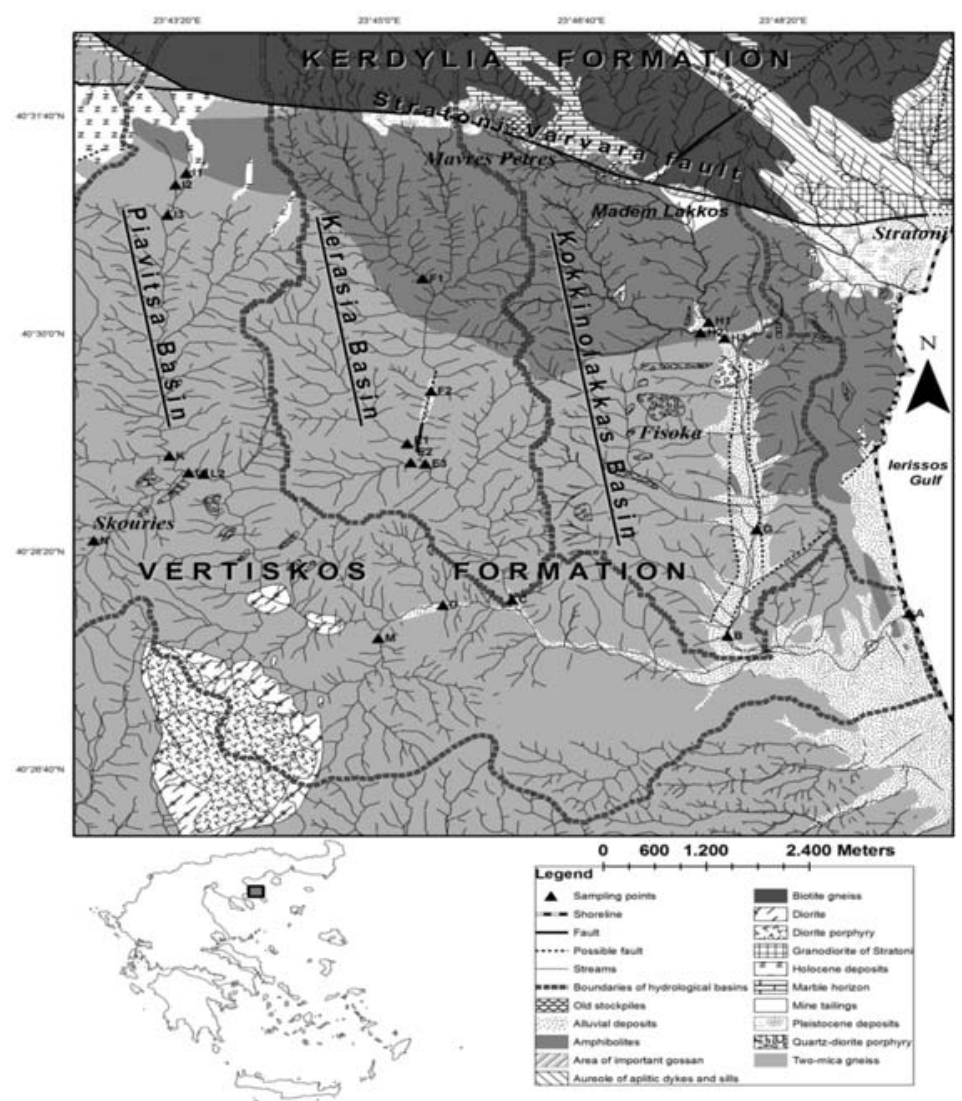

Fig. 1: Map of the study area showing geology, hydrological basins, old ore stockpile disposal areas and sampling points (after Kockel et al. 1977).

ruary 2009, covering all the seasons of a hydrologic year. Twenty one surface water samples were collected during each sampling period, corresponding to a final total number of 80 samples. The sampling points (Fig. 1) are located in three basins, named from east to west as Kokkinolakkas (samples: B, G, H1, H2, and H3), Kerasia (samples: E1, E2, E3, F1 and F2) and Piavitsa (samples: I1, I2, I3, K, L1, L2, M, N). The selection of the water samples was carried out in order to cover the three sub-basins that discharge their waters in Aspolakkas, contributing to its hydrogeochemistry. Samples B and G were only sampled at April 2008 and February 2009 because of lack of water during the dry period. Sample N represents water discharged by the old exploration adit of Skouries deposit.

Samples were taken using 11 polyethylene bottles, cooled during transport and then stored in the refrigerator at $4^{\circ} \mathrm{C}$ until analysis. The polyethylene bottles were previously rinsed with deionised water. Moreover, samples for metal analysis were filtered immediately in the field through $0.45 \mu \mathrm{m}$ Millipore filters, using $60 \mathrm{ml}$-syringes, stored in $50 \mathrm{ml}$ polyethylene bottles under cooling conditions and acidified down to $\mathrm{pH}<2$ with $\mathrm{HNO}_{3}$ at the Hellas-Gold Quality Control Laboratory.

\subsection{Field measurements}

Field measurements such as pH, Electrical Conductivity (EC), Total Dissolved Solids (TDS), Tem- 
perature (T) and Redox Potential (Eh) were measured in-situ using a Multi 350i instrument of WTW. The $\mathrm{pH}$ electrode was calibrated every 10 measurements, using standard solutions of $\mathrm{pH} 7$ and 8 . Stream water discharge was calculated in all cases using a 0012B (Display Unit) Model of Valeport, in previously defined stream sections. Data for the stream water discharges for the sampling period of April 2008 were obtained by the staff of Hellas Gold S.A., since it was not possible to measure the flow rates at the time of our visit to Stratoni village.

At the end of each sampling day, alkalinity $\left(\mathrm{mg} / \mathrm{l}\right.$ as $\left.\mathrm{CaCO}_{3}\right)$ and nitrate $\left(\mathrm{NO}_{3}{ }^{-}\right)$concentrations were measured by using the digital titration method reported by the Hach Instruments (bromocresol greenmethyl red indicator using $\mathrm{H}_{2} \mathrm{SO}_{4}$ ) for total alkalinity and the Hach DR850 portable colorimeter for the determination of nitrate.

\subsection{Chemical analyses}

Chemical analyses were performed at the Department of Geology and Geoenvironment of National and Kapodistrian University of Athens, the ACME Analytical Laboratories Ltd of Canada, and at the Laboratory of Quality Control of "Hellas Gold S.A." at Stratoni. In particular, $\mathrm{K}^{+}, \mathrm{Na}^{+}, \mathrm{Ca}^{++}, \mathrm{Mg}^{++}$ and $\mathrm{SO}_{4}{ }^{2-}$ concentrations were measured at the Laboratory of Quality Control at Stratoni while $\mathrm{Cl}^{-}$, $\mathrm{Pb}, \mathrm{Zn}, \mathrm{Mn}, \mathrm{Cu}, \mathrm{Ni}, \mathrm{Cr}$, and $\mathrm{Cd}$, at the Laboratory of Economic Geology and Geochemistry, University of Athens. Arsenic (As) concentration was only measured for November and February sampling periods at ACME Analytical Laboratories. Fe concentration was measured at the Laboratory of University of Athens (sampling periods April and July) and at ACME Analytical Laboratories (sampling periods November and February).

Sulphate was gravimetrically measured as $\mathrm{BaSO}_{4}$, while chloride was measured photometrically using a Hach DR/4000 apparatus (detection limits being $1 \mathrm{mg} / \mathrm{l}$ and $0.24 \mathrm{mg} / \mathrm{l} \mathrm{respectively).} \mathrm{Heavy}$ metal (Fe for sampling periods April and July, $\mathrm{Pb}, \mathrm{Cu}, \mathrm{Ni}, \mathrm{Cr}$ and $\mathrm{Cd}$ ) concentrations were determined by graphite furnace, Atomic Absorption Spectroscopy (Perkin Elmer 1100B) whereas Zn and Mn were analysed by graphite furnace and by flame, Atomic Absorption Spectroscopy (Perkin Elmer 1100B), when necessary. Detection limits were calculated by standard deviations from 5 measurements of blank. Detection limits of graphite furnace (AAS) were: $5 \mu \mathrm{g} / \mathrm{l}$ for Fe, $1 \mu \mathrm{g} / \mathrm{l}$ for Pb, $5 \mu \mathrm{g} / \mathrm{l}$ for $\mathrm{Zn}, 1 \mu \mathrm{g} / \mathrm{l}$ for $\mathrm{Mn}, 0.5 \mu \mathrm{g} / \mathrm{l}$ for $\mathrm{Cu}, 1 \mu \mathrm{g} / \mathrm{l}$ for $\mathrm{Ni}, 0.5 \mu \mathrm{g} / \mathrm{l}$ for $\mathrm{Cr}$ and $0.5 \mu \mathrm{g} / \mathrm{l}$ for $\mathrm{Cd}$ whereas the detection limit of flame (AAS) was $0.01 \mathrm{mg} / \mathrm{l}$ for $\mathrm{Zn}$ and $\mathrm{Mn}$. Potassium, $\mathrm{Na}, \mathrm{Ca}$ and $\mathrm{Mg}$ concentrations were determined by Inductively Coupled Plasma Emission Spectroscopy (ICP/AES) with detection limits being $1 \mu \mathrm{g} / \mathrm{l}, 1 \mu \mathrm{g} / \mathrm{l}, 5 \mu \mathrm{g} / \mathrm{l}$ and $1 \mu \mathrm{g} / \mathrm{l}$ respectively. Arsenic and Fe (November and February sampling periods) were measured by Inductively Coupled Plasma Mass Spectroscopy (ICP/MS) with detection limits being 0.5 and $10 \mu \mathrm{g} / 1$ respectively.

Certified international reference materials for trace element content (low and high level) were also analysed in order to check the accuracy of the analytical data and close agreement with certified values was achieved for all metals. The accuracy of chemical analyses was also checked by the anion-cation balance, being lower than $5 \%$ for $80 \%$ of the total number of water samples.

\section{Results and Discussion}

\subsection{Basic statistics of physico-chemical parameters}

All the streams are characterised by alkaline $\mathrm{pH}$ values (mean 8.1) and present wide range of concentrations for most of the analysed parameters like EC and $\mathrm{SO}_{4}{ }^{2-}, \mathrm{HCO}_{3}{ }^{-}, \mathrm{Ca}^{2+}, \mathrm{Mg}^{2+}, \mathrm{Mn}$ and $\mathrm{Zn}$, having a range of 328-1669 $\mu \mathrm{S} / \mathrm{cm}, 28-857 \mathrm{mg} / 1,79-265 \mathrm{mg} / \mathrm{l}, 40-231 \mathrm{mg} / \mathrm{l}, 11-94 \mathrm{mg} / 1,3-7899 \mu \mathrm{g} / \mathrm{l}$ 


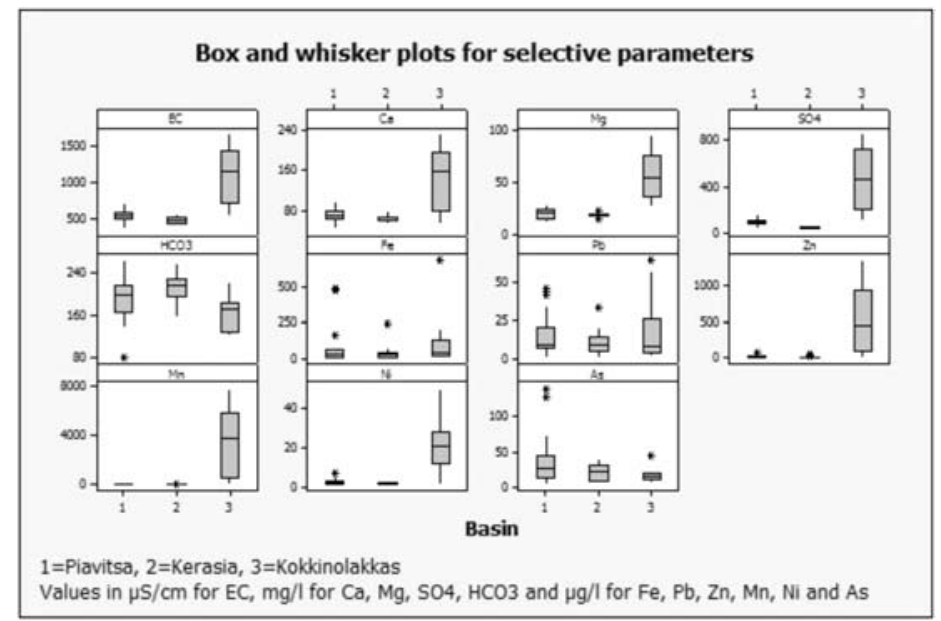

Fig. 2: Box and whisker plots for selected parameters of the three studied basins.

\begin{tabular}{|c|c|c|c|c|c|c|c|}
\hline & Parameter & Unit & Mean & Median & Mn & Max & $\begin{array}{l}\text { Standard } \\
\text { Deviation }\end{array}$ \\
\hline \multirow{12}{*}{ Piavitsa } & EC & ISS/cm & 514 & 520 & 328 & 685 & 79.71 \\
\hline & Ca & mgl/ & 685 & 65.7 & 40 & 96 & $12 \%$ \\
\hline & $\mathbf{M g}$ & $\mathbf{m g} \boldsymbol{n}$ & 18.5 & 18.5 & 11 & 27 & 4.84 \\
\hline & $\mathrm{HCO}_{3}$ & $\mathbf{m g h}$ & 193.6 & 200 & 79 & 265 & 37.54 \\
\hline & $\mathrm{SO}_{4}$ & $\mathbf{m g} /$ & 924 & 937 & 28 & 151 & 29.90 \\
\hline & $\mathrm{Fe}$ & $\mathbf{p g} \mathbf{1}$ & 66.4 & 30.5 & 9 & 489 & 116.80 \\
\hline & $\mathbf{P b}$ & pgl & 14.8 & 9.6 & 2 & 15 & 11.19 \\
\hline & Zn & $|\mathbf{p g}|$ & 221 & 14.3 & 5 & 70 & 15.77 \\
\hline & Mn & pgl & 37.8 & 23.5 & 5 & 106 & 33.28 \\
\hline & $\mathbf{N i}$ & |pgl & 26 & 2 & 1 & 7 & 1.56 \\
\hline & Cd & pgl & 1 & 1 & 1 & 1 & 0 \\
\hline & As & |k9) & 39.1 & 27.6 & 1 & 111 & 39.65 \\
\hline \multirow{12}{*}{ Kerasia } & EC & pS/cm & 455.4 & 458 & 376 & 536 & 47.47 \\
\hline & Ca & $\mathbf{m g} /$ & 50.9 & 58.4 & 51 & 75 & 5.96 \\
\hline & $\mathbf{M g}$ & $\operatorname{mgn}$ & 17 & 16.9 & 13 & 21 & 1.64 \\
\hline & $\mathrm{HCO}_{3}$ & $\mathbf{m g n}$ & 2128 & 215.5 & 155 & 260 & 24.55 \\
\hline & $\mathrm{SO}_{4}$ & $\mathrm{mg} /$ & 44.2 & 43 & 31 & 61 & 8. 12 \\
\hline & $\mathrm{Fe}$ & pg/1 & 424 & 32 & 12 & 242 & 51.97 \\
\hline & $\mathbf{P b}$ & |pg/ & 10.9 & 10 & 1 & 33 & 7.15 \\
\hline & Zn & |pgn & 127 & 11 & 3 & 50 & 9.04 \\
\hline & $\mathbf{M n}$ & pgl & 9.7 & 8.8 & 3 & 26 & 5.19 \\
\hline & $\mathbf{N}$ & |pg/ & 1.7 & 1.5 & 1 & 3 & 0.84 \\
\hline & Cd & pgin & 1 & 1 & 1 & 1 & 0 \\
\hline & As & eg/ & 21.6 & 21.8 & 7 & 42 & 13.06 \\
\hline \multirow{12}{*}{ Kobkinotatbes } & EC & $\mathrm{NS/ \textrm {cm }}$ & 1117.4 & 1135 & 510 & 1669 & 390.64 \\
\hline & Ca & mgl & 148.1 & 157 & 52 & 231 & 63 \\
\hline & $\mathbf{M g}$ & mgn & 56.8 & 53 & 26 & 94 & 2261 \\
\hline & $\mathrm{HCO}_{3}$ & mgn & 1627 & 170.5 & 122 & 222 & 31.14 \\
\hline & $\mathrm{SO}_{4}$ & $\mathbf{m g n}$ & 4829 & 461.6 & 107 & 857 & 260.64 \\
\hline & $\mathrm{Fe}$ & $|\mathbf{m g}|$ & 119.9 & 435 & 9 & 681 & 186.85 \\
\hline & $\mathbf{P b}$ & pgy & 17.8 & $\mathbf{8 . 5}$ & 2 & 64 & 20.61 \\
\hline & Zn & $|\mathbf{p g}|$ & 546 & 440 & 10 & 1350 & 436.78 \\
\hline & Mn & $\mid \mathbf{m g} \mathbf{1}$ & 3547.3 & 3887.5 & 91 & 7899 & 2611.59 \\
\hline & $\mathbf{N h}$ & $\mathbf{p g} \mathbf{1}$ & 21.4 & 20.8 & 1 & 50 & 15.52 \\
\hline & Cd & |pg| & 4.1 & 3.5 & 2 & 8 & 189 \\
\hline & As & pol & 18.8 & 16.2 & 8 & 45 & 11.43 \\
\hline
\end{tabular}

Table 1: Basic statistics of selected analysed parameters for the three basins. Data from the 4 sampling periods.

and 3-1350 $\mu \mathrm{g} / \mathrm{l}$ respectively. In contrast, $\mathrm{K}, \mathrm{Na}, \mathrm{NO}_{3}$, and $\mathrm{Cl}$ concentrations are very low presenting a range of 1-13 mg/l, 7-23 mg/l, 2-8 mg/l and 5-20 mg/l respectively whereas $\mathrm{Fe}, \mathrm{As}, \mathrm{Pb}, \mathrm{Ni}, \mathrm{Cu}$ and Cd mean values are $69.1 \mu \mathrm{g} / 1,29.44 \mu \mathrm{g} / 1,14.14 \mu \mathrm{g} / 1,8.27 \mu \mathrm{g} / 1,4.5 \mu \mathrm{g} / \mathrm{l}$ and $3.08 \mu \mathrm{g} / \mathrm{l}$ respectively.

Because of the great variability of some of the above mentioned analysed parameters, it was considered necessary to study the three basins individually. Table 1 shows a summary of the basic sta- 
tistics of selected analysed parameters for each of the studied basins (Piavitsa, Kerasia and Kokkinolakkas), for all the sampling periods. Sample A was not included in order to obtain the basic statistics and was excluded for the further treatment since its chemistry is slightly affected by the sea (mean concentrations of $\mathrm{Cl}^{-}$and $\mathrm{Na}^{+}$being $255 \mathrm{mg} / \mathrm{l}$ and $128 \mathrm{mg} / \mathrm{l}$ respectively). The concentrations of major parameters such as $\mathrm{K}, \mathrm{Na}, \mathrm{NO}_{3}$ and $\mathrm{Cl}$ and trace elements such as $\mathrm{Cu}$ and $\mathrm{Cr}$ are either very low or close to the detection limit of the analytical technique and they have been omitted in Table 1. The concentrations of these elements were always below the drinking water standards $(200 \mathrm{mg} / \mathrm{l}$ for $\mathrm{Na}, 50 \mathrm{mg} / \mathrm{l}$ for $\mathrm{NO}_{3}, 250 \mathrm{mg} / \mathrm{l}$ for $\mathrm{Cl}, 2000 \mu \mathrm{g} / \mathrm{l}$ for $\mathrm{Cu}$ and $50 \mu \mathrm{g} / \mathrm{l}$ for $\mathrm{Cr}$, according to the $\mathrm{EU}$ Council Directive 98/83/EEC on the quality of water intended for human consumption).

\subsection{Comparison between the three basins}

Most of the studied parameters present distinct differences between the three sub-basins of the area. Figure 2 visually displays the range of concentrations of the major constituents and the main differences between the three sub-basins as box-and-whisker plots, including values from all the sampling periods. The length of box indicates the interquartile range while the heavy horizontal line inside the box indicates the median. Whiskers are lines that extend from the box to the highest and lowest values excluding outliers $(*)$. Outliers are defined as cases in which the values are between 1.5 and 3 times larger than the length of the box from its upper or lower border.

In general, it is observed that elemental concentrations in water samples from Kokkinolakkas are higher and of a wider range when compared to concentrations from Kerasia and Piavitsa samples. In particular, $\mathrm{EC}, \mathrm{Ca}^{2+}, \mathrm{Mg}^{2+}, \mathrm{SO}_{4}^{2-}, \mathrm{Zn}, \mathrm{Mn}, \mathrm{Ni}$ and $\mathrm{Cd}$ (Table 1) present considerable higher concentrations in the water samples from Kokkinolakkas basin indicating different natural and/or anthropogenic factors that control its water chemistry. On the contrary, concentrations of As in Piavitsa, where there is no mining activity, are approximately twice as much as the concentration in Kokkinolakkas whereas $\mathrm{Fe}$ and $\mathrm{Pb}$ concentrations do not show a clear trend presenting outliers and a subsequent wide range of values in the three basins. Same differences in water quality from the three basins were also reported in the study by Lazaridou-Dimitriadou et al. 2004.

Regarding the EU Council Directive 98/83/EEC, Pb, Mn and As concentrations in Piavitsa basin usually exceed the parametric values of $10 \mu \mathrm{g} / 1,50 \mu \mathrm{g} / 1$ and $10 \mu \mathrm{g} / 1$ respectively, while Fe concentrations of sample N (old exploration adit of Skouries) exceed the guideline value of $200 \mu \mathrm{g} / \mathrm{l}$. Concentrations of all the other elements are lower than the regulatory limits. Kerasia basin shows a similar pattern for all the studied elements, except for the fact that Mn levels are always below the drinking quality standards. Only sample F2 for February sampling period exceeds the corresponding limit of $200 \mu \mathrm{g} / \mathrm{l}$, in regard to Fe concentration. Finally, water samples from Kokkinolakkas present $\mathrm{SO}_{4}, \mathrm{Mn}, \mathrm{Ni}, \mathrm{Cd}$, As and $\mathrm{Pb}$ concentrations that are usually considerable higher than the parametric values. The only exception is sample $\mathrm{H} 2$, which presents its own water chemistry.

Regarding the permissible environmental limits for surface waters intended to be used for irrigation, set for Chalkidiki Prefecture (Dec. No 96400/85, G.G. 573/B/85), all the studied water samples for all the analysed parameters present concentrations that do not exceed the corresponding values, except for Mn concentrations at Kokkinolakkas basin (the permissible limit for Mn is $2000 \mu \mathrm{g} / \mathrm{l}$ ).

In respect with water types, according to the Piper diagrams presented in Figure 3 for April sampling period, two groups of waters can be differentiated. The first group is characterised by high $\mathrm{Ca}-\mathrm{HCO}_{3}$ and includes all samples from Kerasia and Piavitsa (except for sample M), as well as sample $\mathrm{H} 2$ from Kokkinolakkas stream, indicating the influence on water chemistry of the Ca-rich geological for- 

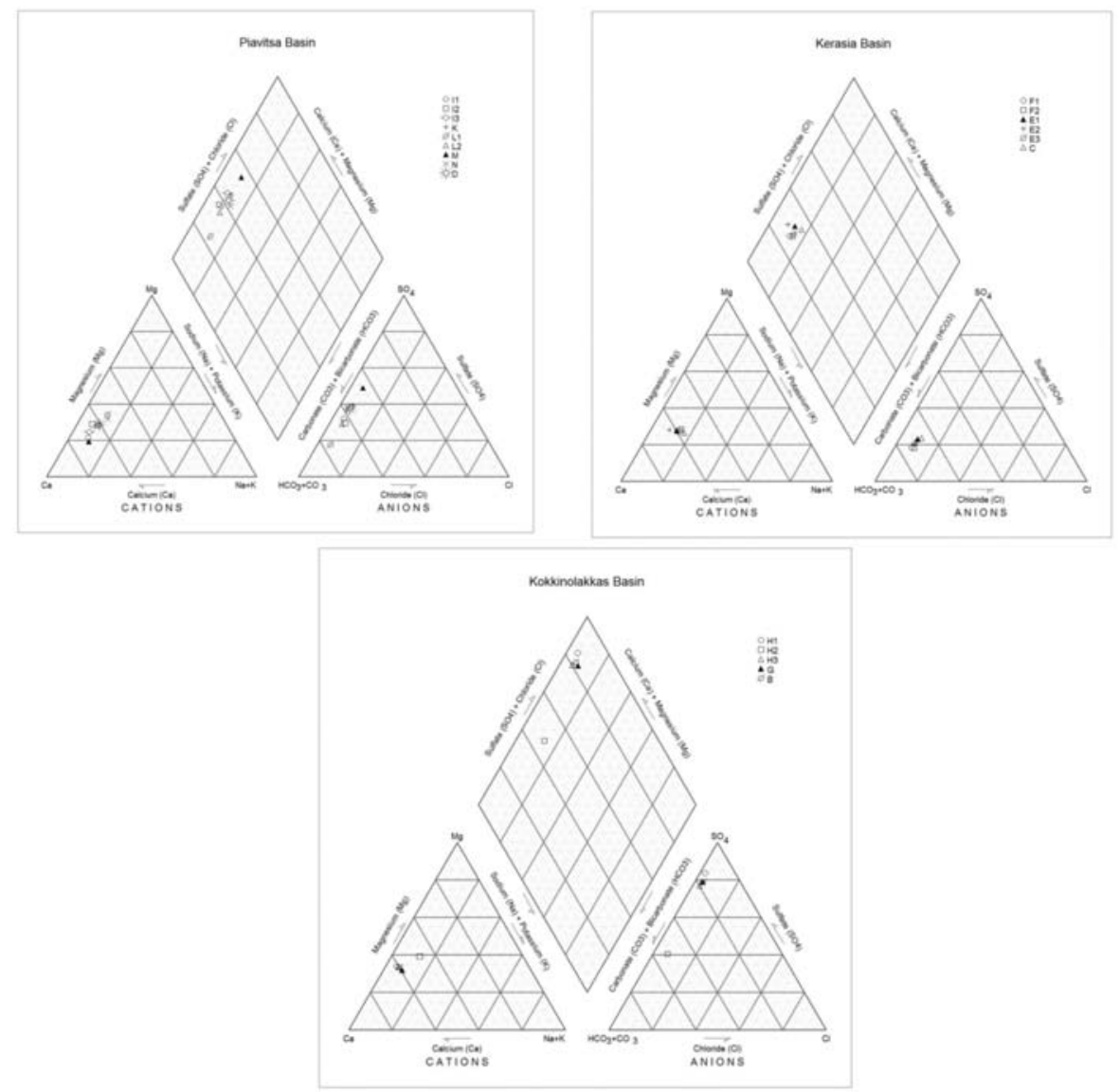

Fig. 3: Piper diagrams for the water samples for April sampling period.

mations outcropping at the North part of the studied area (marbles of Kerdylia formation). The second group is characterised by high $\mathrm{Ca}-\mathrm{SO}_{4}$, and consists of samples from Kokkinolakkas and sample $\mathrm{M}$ from Piavitsa, reflecting the influence of the polymetallic sulphide ore deposits.

The chemistry of sample H2, located within Kokkinolakkas, presents considerable differences in comparison with the other water samples of this basin, presenting the following mean concentrations: $118 \mathrm{mg} / \mathrm{l}$ for $\mathrm{SO}_{4}{ }^{2-}, 56 \mathrm{mg} / \mathrm{l}$ for $\mathrm{Ca}^{2+}, 29 \mathrm{mg} / 1$ for $\mathrm{Mg}^{2+}, 4.5 \mu \mathrm{g} / \mathrm{l}$ for $\mathrm{Pb}, 13 \mu \mathrm{g} / 1$ for As, $17 \mu \mathrm{g} / \mathrm{l}$ for $\mathrm{Zn}$, and $149 \mu \mathrm{g} / \mathrm{l}$ for $\mathrm{Mn}$, while concentrations of $\mathrm{Ni}$ and $\mathrm{Cd}$ are below the detection limits. As a consequence, it may be suggested that it derives from a different area and drains different materials, being obviously unaffected by the presence of the extended sulphide mineralisation. Apart from the apparent influence of the sulphide mineralization on the water chemistry, the existence of various old stockpiles of mineral wastes that had been deposited in the past along Kokkinolakkas (Papakonstantinou et al. 1996), particularly at the North part of the stream (Figure 1), may have contributed to the elevated concentrations of sulphate and metals for the rest of the samples of this basin.

Figure 4 presents the Ficklin diagram for the water samples of Kokkinolakkas basin (except for sample H2), including all the sampling periods. The Ficklin diagram is used to describe the charac- 


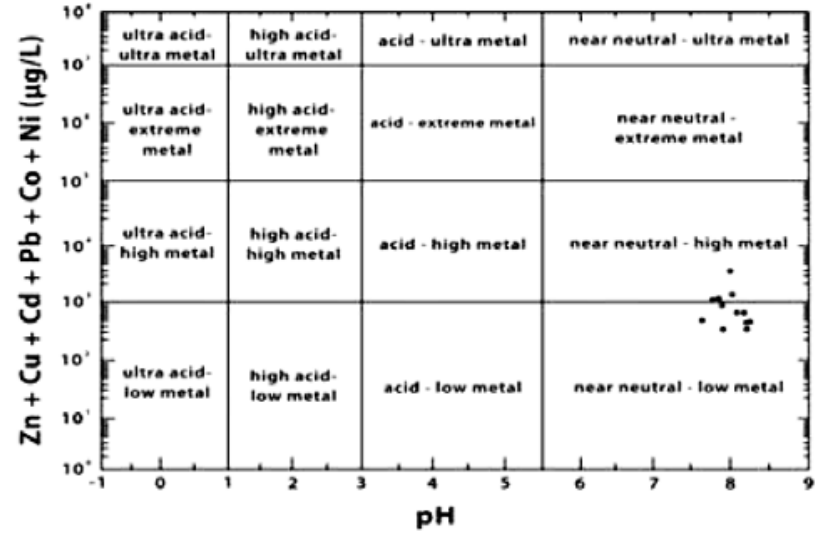

Fig. 4: Ficklin diagram showing the sum of dissolved base metal concentrations as a function of $\mathrm{pH}$.

teristic drainage signature of different types of ore deposits (Ficklin et al. 1992). Differences in the sum of base metals ( $\mathrm{Zn}, \mathrm{Cu}, \mathrm{Cd}, \mathrm{Pb}, \mathrm{Co}$ and $\mathrm{Ni}$ ) allow to differentiate between different geological controls on water composition. The plotted waters are characterised by near neutral values of $\mathrm{pH}$ and low (sum of base metals $<10^{3}$ ) to high ( sum of base metals $>10^{3}$ ) metal dissolved concentrations. The cluster of points falls within the field typically associated with pyrite-sphalerite-galenachalcopyrite ores with hydrothermal carbonates or carbonate-rich host rocks (Seal et al., 2002).

\subsection{Seasonal variation}

Figure 5 displays the seasonal variation of $\mathrm{SO}_{4}{ }^{2-}$ upstream to downstream for each of the studied basin. November is included in the dry period since no rainfall was recorded until then whereas April is included in the wet period. Major ions content, such as $\mathrm{SO}_{4}{ }^{2-}$, decrease in the wet period (April and February) because of dilution caused by the heavy rainfall during those months. This is true for all the samples from the three basins. Calcium, $\mathrm{K}^{+}, \mathrm{Na}^{+}, \mathrm{Mg}^{2+}$ and $\mathrm{HCO}_{3}{ }^{-}$are not represented in the figure but they exhibit a similar pattern.

In contrast, Zn concentration in Kokkinolakkas water samples (Figure 5), reaches maximum values during the wet period (April and February). The same behaviour is also noticed for $\mathrm{Pb}, \mathrm{Cd}$, As and $\mathrm{Ni}$ (not displayed in the figure). A possible explanation for this could be the fact that during the wet period, large quantities of water dissolve solid phases that hold these metals and are associated either with minerals of the primer sulphide mineralisation or with materials of the old mineral waste stockpiles. As a result stream water becomes enriched in those metals. Manganese reaches maximum values in winter but is also present in high concentrations during the rest of the sampling periods. For the waters of the other two basins, the seasonal pattern is unclear, and no safe conclusions can be conducted.

\subsection{Comparison with previous data}

There are extended historical monitoring data for the entire area of the three studied basins. As it has been already mentioned, concentrations of Mn for Kokkinolakkas basin (samples H1 and H3) exceed the permissible limits set by Chalkidiki Prefecture for irrigation water. The existence of the old stockpiles, upstream of the sampling area, can be considered as a major source for these high concentrations. A comparison of data produced by this study with earlier measurements seems to be necessary in order to evaluate the management of these deposits. Figure 6 shows that there is a significant gradual decrease in the concentration of Mn approaching or exceeding $60 \%$ of the concentration 
Seasonal evolution of $\mathrm{SO}_{4}$ for Piavitsa

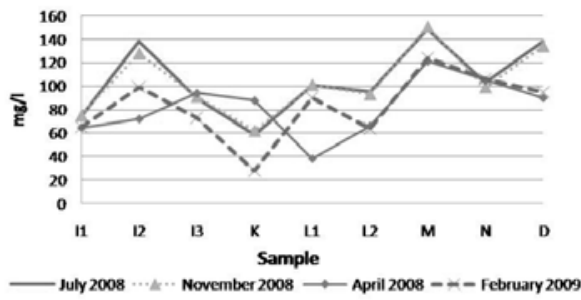

\section{Seasonal evolution of $\mathrm{SO}_{4}$ for Kokkinolakkas}

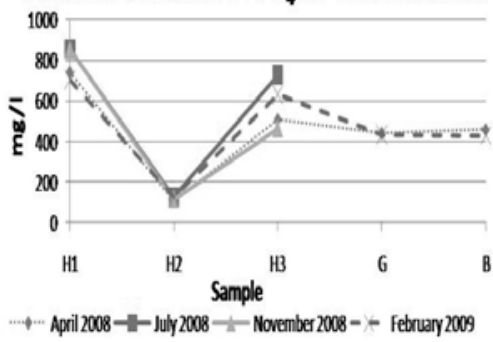

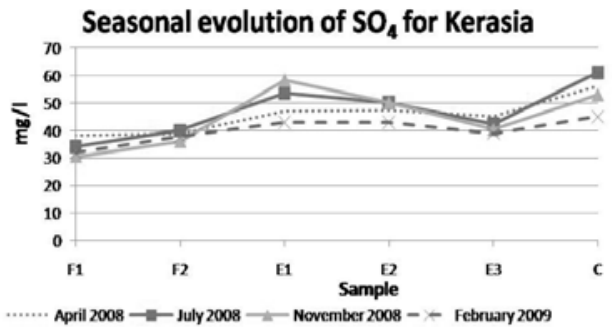

Seasonal evolution of $\mathrm{Zn}$ for Kokkinolakkas

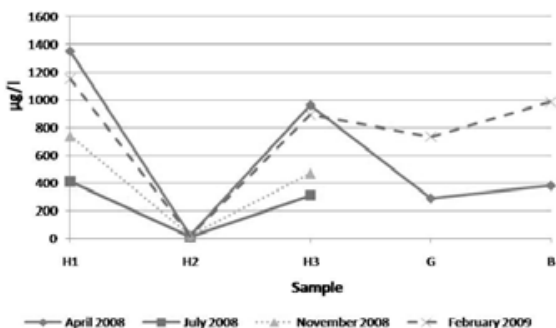

Fig. 5: Seasonal evolution of selected analysed variables.
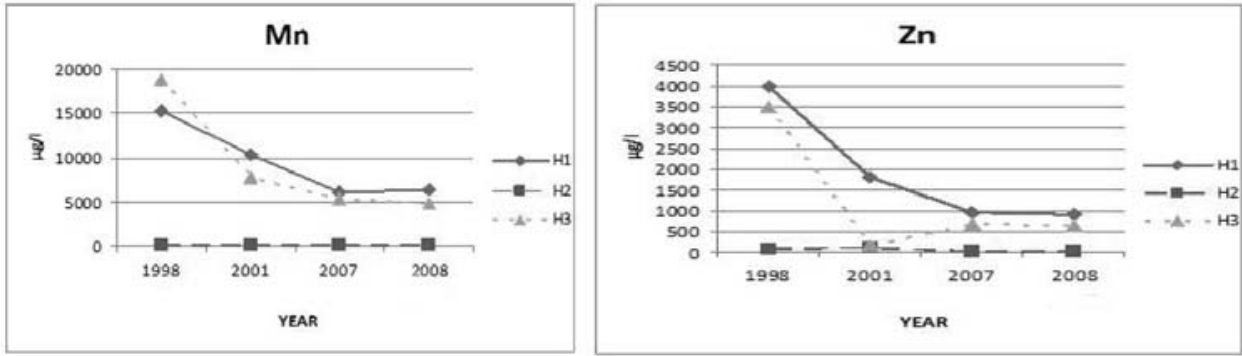

Fig. 6: Evolution of $\mathrm{Mn}$ and $\mathrm{Zn}$ concentrations in Kokkinolakkas stream water during the last decade.

measured in 1998. Similar behaviour is noticed for a variety of other metals i.e., Fe, $\mathrm{Zn}, \mathrm{Ni}, \mathrm{Cd}$ and As, for which concentrations are now consistent with the permissible limits for surface waters of Chalkidiki Prefecture. For the water of the other two studied basins, the comparison with previous data showed that there is not any significant change in the concentrations of the analysed parameters.

\section{Conclusions}

The studied area of Asprolakkas basin, located at North East Ckalkidiki, has a history of intense mining of sulphide deposits, which is evitable in the chemistry of water samples from Kokkinilolakkas stream except for the chemistry of sample $\mathrm{H}_{2}$. The stream water of Kerasia and Piavitsa basins has a different chemical composition, influenced to a lesser extent by oxidation and metal release from outcrops of the sulphide mineralization occurring in the wider area. Only slight differences 
were observed with respect to seasonal variation of the chemistry of stream water. During spring and winter sampling periods (wet period), the lowest $\mathrm{SO}_{4}{ }^{2-}, \mathrm{Ca}^{2+}, \mathrm{Na}^{+}, \mathrm{K}^{+}, \mathrm{Mg}^{2+}, \mathrm{HCO}_{3}{ }^{-}$concentrations were recorded, caused by the dilution of superficial runoff water, while $\mathrm{Zn}, \mathrm{Pb}, \mathrm{As}, \mathrm{Cd}$, and Ni concentrations for Kokkinolakkas stream water reach maximum values during the wet period. The comparison of chemical analyses with historical data, showed a gradual decrease regarding the concentrations of several metals in the water of Kokkinolakkas stream.

\section{Acknowledgments}

The authors wish to thank Prof. N. Skarpelis for his detailed and helpful comments and suggestions that significantly improved this paper.

\section{References}

European Union Council: 1998, 'Council Directive on the quality of water intended for human consumption, 98/83/EC', Official Journal of the European Communities, Vol 330, 32-54.

Ficklin, W.H., Plumlee, G.S., Smith, K.S., McHugh, J.B., 1992. Geochemical classification of mine drainages and natural drainages in mineralised areas. In: (Kharaka, Y.K., Maest, A.S. Eds.), Proceedings, $7^{\text {th }}$ International Symposium. Water Rock interaction, 381-384.

Frei, Robert., 1995. Evolution of Mineralising Fluid in the Porphyry Copper System of the Skouries Deposit, Northeast Chalkidiki (Greece): Evidence from Combined $\mathrm{Pb}-\mathrm{Sr}$ and Stable Isotope Data. Economic Geology, 90, 746-762.

Greek Government Gazette 573/B/85, Prefectural Decision No 96400/85, on the disposal terms of liquid industrial wastes into natural receivers of Chalkidiki Prefecture.

Kalogeropoulos, S.I., Kilias, S.P., Bitzios, D.D., Nicolaou, M., and Both, R.A., 1989. Genesis of the Olympias Carbonate-Hosted Pb-Zn (Au, Ag) Sulfide Ore Deposit, Eastern Chalkidiki Peninsula, Northern Greece. Ecomomic Geology, 84, 1210-1234.

Kockel, F., Mollat, H., and Gundlach, H., 1975. Hydrothermally Altered and (Copper) Mineralized Porphyritic intrusions in the Serbo-Makedonian Massif (Greece). Mineral Deposita (Berl.), 10, 195-204.

Kockel,F., Mollat, H., and Walther, H.W., 1977. Erläuterungen zur geologischen Karte der Chalkidiki und angrenzender Gebiete 1:100000 (Nord-Griechenland). Hannover, Bundesanstalt Geowiss. Rohstoffe, 119 p.

Kroll, T., Müller, D., Seifert, T., Herzig, P.M., and Schneider, A., 2002. Petrology and geochemistry of the shoshonite-hosted Skouries porphyry $\mathrm{Cu}$-Au deposit, Chalkidiki, Greece. Mineralium Deposita, 37, 137-144.

Lazaridou-Dimitriadou, M., Koukoumides, C., Lekka, E., and Gaidagis, G., 2004. Integrative evaluation of the ecological quality of metalliferous streams (Chalkidiki, Macedonia, Hellas). Environmental Monitoring and Assessment, 91, 59-86.

Nebel, Mark.L., Hutchinson, R.W., and Zartman, R.E., 1991. Metamorphism and Polygenesis of the Madem Lakkos Polymetallic Sulfide Deposit, Chalkidiki, Greece. Economic Geology, 86, 81-105.

Nicolaou, M., \& Kokonis, D., 1980. Geology and development of Olympias mine, eastern Chalkidiki, Macedonia, Greece. In: (J.M. Jones, ed.), Complex Sulfide Ores. Inst. Mining Metallurgy, London.

Papakonstantinou, A., Veranis, N., \& Polyzonis, E., 1996. Hydrochemical-Hydrogeological Study of Olympias-Stratonion, Chalkidiki (in Greek). Technical Report. IGME, Thessaloniki.

Seal II, R.R., Foley, N.K., Wanty, R.B., 2002. Introduction to geoenvironmental models of mineral deposits. In: Seal II, R.R., Foley, N.K. (Eds.), Progress on Geoenvironmetal Models for Selected Mineral Deposit Types, US Geol. Surv. Open file Rep.02-195. 